\title{
DIAGNOSTIC PERFORMANCE OF AN IMMUNOASSAY FOR SIMULTANEOUS DETECTION OF HCV CORE ANTIGEN AND ANTIBODIES AMONG HAEMODIALYSIS PATIENTS
}

\author{
Wafaa M. El-Emshaty ${ }^{1}$, Douaa Raafat ${ }^{1}$, Doaa M. Elghannam¹, Niveen Saudy ${ }^{1 *}$, Ehab E. Eltoraby ${ }^{2}$, Abd Elhameed A. \\ Metwalli ${ }^{2}$
}

${ }^{1}$ Department of Clinical Pathology, Mansoura University, Egypt; ${ }^{2}$ Internal Medicine Departments Faculty of Medicine, Mansoura University, Egypt.

Submitted: November 10, 2009; Approved: June 21, 2010.

\begin{abstract}
Nosocomial transmission of HCV is a concern in haemodialysis (HD) units worldwide. Diagnosis of HCV infection among dialysis patients is currently based on the detection of anti HCV antibodies by ELISA, and is confirmed by HCV RNA. The average window period between HCV infection and seroconversion with new generations of $\mathrm{HCV}$ antibody tests remains approximately 70 days with more prolonged period among dialysis patients. In this study we assessed the diagnostic performance of an immunoassay designed for simultaneous detection of anti HCV antibodies and core antigen in one step in comparison to qualitative RTPCR and anti HCV antibodies detection test among Egyptian haemodialysis patients. The studied patients were 39 chronic renal failure patients on maintenance haemodialysis. The results obtained in the present study revealed $\mathrm{HCV}$ infection of $56.4 \%$. Combined $\mathrm{Ag} / \mathrm{Ab}$ test detected 3 out of the 4 anti-HCV negative viraemic patients who were in the window period. The sensitivity, specificity and accuracy of the test were higher than that of anti $\mathrm{HCV}$ antibodies detection test $(95.45 \%, 94.1 \%$ and $94.87 \%$ versus $81.8 \%, 88.23 \%$ and $84.6 \%$ ) and they were raised to $100 \%$ on combining its positivity with liver enzymes elevation results. Therefore, this simple combined $\mathrm{Ag} / \mathrm{Ab}$ test can be applied for early detection of $\mathrm{HCV}$ infection during window period among HD patients as an alternative to HCV RNA detection.
\end{abstract}

Key words: Egypt, haemodialysis; HCV; HCV core antigen; immunoassay.

\section{INTRODUCTION}

The hepatitis $\mathrm{C}$ virus $(\mathrm{HCV})$ is a prevalent infectious disease generally contracted via HCV infected blood and blood products (33). Egypt has the highest seroprevalence for $\mathrm{HCV}$ with rates up to $20 \%$ in some areas. The high rate of $\mathrm{HCV}$ transmission continues both iatrogenically and within the community (11).

Nosocomial transmission of $\mathrm{HCV}$ is a concern in haemodialysis (HD) units worldwide $(2,6,13,31)$. In these patients, blood transfusions and long term dialysis are risk factors for transmission of $\mathrm{HCV}$ (28)

Prompt assessment of devovo HCV among dialysis patients is required to limit nosocomial spread of HCV (12). Routine 
testing for alanine amino transferase (ALT) and HCV RNA are recommended by CDC for anti-HCV negative patients (9).

Different generations of anti HCV antibody assays have been developed with improved performance that reduce the risk of $\mathrm{HCV}$ transmission by reducing the window period from 82 (7) to 66 days with later generation assays $(5,10)$.

To prevent transmission of HCV during the window period before seroconversion, nucleic acid amplification technology (NAT) has been developed that include polymerase chain reaction (PCR), transcription mediated amplification (TMA) (26), and signal amplification [branched chain DNA (bDNA)] (32). However, such techniques are expensive, may give false positive or negative results (12), could not totally prevent $\mathrm{HCV}$ transmission and anti HCV screening must be combined $(8,18$, 25).

Some studies indicate that $\mathrm{HCV}$ core antigen can be detected in the window period before seroconversion and $\mathrm{HCV}$ core antigen levels correlate well with HCV RNA levels (4, 24, 29). An immunoassay based on the simultaneous detection of HCV core Ag. and antibodies has been developed (19).

The aim of the present study is to assess the diagnostic performance of this assay for early detection of $\mathrm{HCV}$ infection during the window period among haemodialysis patients in comparison to anti HCV antibodies and HCV RNA detection tests.

\section{MATERIALS AND METHODS}

Subjects included in this study were 39 chronic renal failure patients attending Renal Dialysis Unit, Internal Medicine Department, Mansoura University hospital. They were $12(30.8 \%)$ males and $27(69.2 \%)$ females with mean ages of $49.9 \pm 12.5$ years. Their ages ranged from 24 to 75 years and duration of dialysis ranged from $1-18$ years. The study was approved by ethical Committee of Mansoura Faculty of Medicine, Egypt. Written consents were obtained from all patients.

Blood samples were collected from patients before dialysis into 2 tubes, one EDTA tube for hemoglobin estimation and one plain tube. Sera were separated into 3 aliquots, one used for estimation of creatinine, calcium, phosphorus, ALT, AST levels and anti HCV antibodies. The other two aliquots were stored at $-70^{\circ} \mathrm{C}$ until used for assessment of $\mathrm{HCV}$ infection by using $\mathrm{HCV}$ core $\mathrm{Ag} / \mathrm{Ab}$ combination assay and qualitative HCV RT- PCR.

\section{Anti HCV antibodies detection}

Anti HCV antibodies were detected by Murex anti HCV (version 4) according to the manufacturer instructions. An ELISA which utilize microplates coated with HCV specific antigens derived from "core" and "ns" regions encoding core peptide, recombinant NS3, NS4 and NS5 peptides.

\section{Combined Ag/Ab detection}

Murex Ag/Ab HCV combination assay (Murex Biotech S.A [pty] Ltd. UK) was used which is an enzyme immunoassay utilize wells that are coated with anti-core monoclonal antibody, and recombinant antigen and peptides representing the immunodominant regions of the NS3 and core viral antigens. $\mathrm{HCV}$ core $\mathrm{Ag}$ and/or $\mathrm{Ab}$ to $\mathrm{HCV}$ present in any test specimens or control sera bound to the coated micro well during the first incubation. Subsequently peroxidase labeled conjugate, containing antigenic epitopes from NS3 and core together with anti-core monoclonal antibodies was added which in turn bound to the reagents on the wells.

In reactive wells, addition of substrate solution containing 3,3`, 5,5 tetramethylbenzidine (TMB) and hydrogen peroxide gave a blue green color which was converted to an orange color when the reaction was stopped with $1 \mathrm{~N}$ sulphuric acid.

Samples with absorbance greater than or equal to the cut off were considered reactive while samples with absorbance lower than the cutoff value were negative.

\section{RT-PCR}

RNA was isolated using QIA amp viral RNA mini kit (Cat \# 52904). Frozen sera were thawed immediately before use. Qiagen one step RT- PCR kit (Cat \# 210212) was used for Reverse transcription and amplification with Qiagen primer 6A 
and $6 \mathrm{~B} . \mathrm{HCV}$ positive samples revealed 270 base pairs bands on UV visualization with the guide of DNA marker.

\section{Statistical analysis}

Data entry and analyses were performed using SPSS statistical package version 10 (SPSS, Inc., Chicago, IL, USA). Qualitative data were expressed as numbers and percentages. Sensitivity, specificity and accuracy of tests were carried out using standard equations.

\section{RESULTS}

The studied population represented 39 Egyptian chronic renal failure patients. The sero-prevalence of $\mathrm{HCV} \mathrm{Ab}$ was $20 / 39(51.3 \%)$. The mean $\mathrm{Hb}$, creatinine, calcium and phosphorus levels of patients were 9.6 $\pm 1.4,6.1 \pm 1.4,7.31 \pm 0.7$, and $6.36 \pm 1.2$ respectively.

Of the 20 patients positive for anti HCV antibodies, 18 were confirmed positive by both combined $\mathrm{Ag} / \mathrm{Ab}$ detection test and RT- PCR (7 were with elevated liver enzymes and 11 were with normal liver enzymes), while one patient was positive to combined $\mathrm{Ag} / \mathrm{Ab}$ detection test but negative to $\mathrm{RT}$ PCR (with normal liver enzymes) and only one patient was negative to both assays and his liver enzymes were normal. The other 19 patients were anti HCV negative. Of these patients, 15 were negative to combined $\mathrm{Ag} / \mathrm{Ab}$ test and PCR (14 were with normal liver enzymes and one had elevated enzymes), 4 patients were in the window period: $3 / 4$ were confirmed positive by Ag/Ab test and RT- PCR (two were with normal enzymes and one had elevated enzymes) and the fourth patient was negative to $\mathrm{Ag} / \mathrm{Ab}$ test but positive to RT- PCR test and his liver enzymes were elevated. Analysis of these findings revealed that the highest evaluation parameters (sensitivity, specificity, and accuracy) were with combined Ag/Ab assay with true positvity detected in 21 out of the 22 viraemic patients, while the true negative cases were 16 out of 17 non viraemic patients (Table 1). On the contrary of the evaluation parameters of anti-HCV antibodies that decreased on combining its results with liver enzymes elevations (Table 2), they were raised up to $100 \%$ on combining $\mathrm{Ag} / \mathrm{Ab}$ assay positivity with elevated liver enzymes (Table 3).

Table 1. HCV diagnostic tests versus RT-PCR results in HD patients

\begin{tabular}{lcccccc}
\hline & \multicolumn{2}{c}{ HCV anti- bodies } & \multicolumn{2}{c}{ Combined Ag/Ab } & \multicolumn{2}{c}{ Liver enzymes } \\
\cline { 2 - 7 } \multicolumn{1}{r}{ RT-PCR } & Positive (20) & Negative (19) & Positive (22) & Negative (17) & Elevated (10) & Normal (29) \\
\hline Positive (22) & 18 & 4 & 21 & 1 & 9 & 13 \\
Negative (17) & 2 & 15 & 1 & 16 & 1 & 16 \\
Sensitivity & & $81.8 \%$ & & $95.45 \%$ & $40.9 \%$ \\
Specificity & & $88.23 \%$ & $94.1 \%$ & $94.1 \%$ \\
Accuracy & & $84.6 \%$ & & $94.87 \%$ & & $64.1 \%$ \\
\hline
\end{tabular}

Table 2. Evaluation parameters of combination of anti HCV and liver enzymes elevation results in comparison to RT-PCR

\begin{tabular}{llll}
\hline & \multicolumn{3}{c}{ RT-PCR } \\
\cline { 2 - 4 } & Positive & Negative & Total \\
\hline Anti HCV positive with elevated liver enzymes & 7 & 0 & 7 \\
Anti HCV negative with normal liver enzymes & 2 & 14 & 16 \\
Total & 9 & 14 & 23 \\
Sensitivity & $77.7 \%$ & & \\
Specificity & $100 \%$ & & \\
Accuracy & $91.3 \%$ & & \\
\hline
\end{tabular}


Table 3. Evaluation parameters of combination of $\mathrm{Ag} / \mathrm{Ab}$ detection assay and liver enzymes elevation results in comparison to RT-PCR

\begin{tabular}{llll}
\hline & \multicolumn{3}{c}{ RT-PCR } \\
\cline { 2 - 4 } & $+\mathbf{+ v e}$ & $\mathbf{- v e}$ & Total \\
\hline Ag/Ab positive with elevated liver enzymes & 8 & 0 & 8 \\
Ag/Ab negative with normal liver enzymes & 0 & 14 & 14 \\
Total & 8 & 14 & 22 \\
Sensitivity & $100 \%$ & & \\
Specificity & $100 \%$ & & \\
Accuracy & $100 \%$ & & \\
\hline
\end{tabular}

\section{List of abbreviations}

\begin{tabular}{ll}
\hline Alanine amino transferase & ALT \\
Aspartate amino transferase & AST \\
Branched chain DNA & bDNA \\
Haemodialysis & HD \\
Hepatitis C virus & HCV \\
Nucleic acid testing & NAT \\
Polymerase chain reaction & PCR \\
Tetramethylbenzidine & TMB \\
Transcription mediated amplification & TMA \\
\hline
\end{tabular}

\section{DISCUSSION}

The early diagnosis of hepatitis $\mathrm{C}$ virus (HCV) infection and its control are crucial to prevent further transmission in high risk groups such as hemodialysis (HD) populations (30).

Routine anti - HCV antibody detection is not applicable to confirm HCV infection during early period before anti-HCV antibody has been produced (27), particularly in HD patients who fail to produce rapid strong immune response and have a prolonged serological window phase after a recent $\mathrm{HCV}$ infection (28). Moreover, occult $\mathrm{HCV}$ infection may be common among these patients (30).

HCV RNA assay is difficult and lacks reproducibility which limited its application in the early clinical diagnosis and screening (14). The detection of $\mathrm{HCV}$ antigen enables the diagnosis of $\mathrm{HCV}$ in the preconversion phase, but its high cost prevents its application in developing countries (33).

Currently, there is no published data on the simultaneous detection of $\mathrm{HCV}$ antigen and antibodies in Egyptian HD population. Therefore we assessed a combined $\mathrm{HCV} \mathrm{Ag/Ab}$ assay by ElA in comparison to qualitative RT- PCR and anti $\mathrm{HCV}$ antibodies detection test for early detection of infection among HD patients.

RT-PCR diagnosed HCV infection in 22/39 (56.4\%) HD patients (18 were anti HCV positive and 4 were negative) in this study.

The rate of $\mathrm{HCV}$ infection among HD patients shows great variation (2). Bezerra et al., (6) and Schneeberger et al. (28) recorded $\mathrm{HCV}$ infection of $7 \%$ and $8 \%$ respectively among dialysis patients, while another study proved that $32 \%$ (33 
/102) of studied HD patients have HCV infection, $90 \%$ of these patients had occult HCV (17)

Medhi et al. (23) found that RT-PCR was positive among $56(22.4 \%)$ out of 250 HD patients; $43(17.2 \%)$ were positive for anti- $\mathrm{HCV}$ antibodies and $\mathrm{HCV}$ core Ag. and 13 were positive for $\mathrm{HCV}$ core $\mathrm{Ag}$ only but anti $\mathrm{HCV}$ negative. In Turkish, Yakaryilmaz et al. (34) reported that 39/188 (20.7\%) of HD studied patients have HCV infection and only 9 (4.8\%) of them have serological markers of $\mathrm{HCV}$ infection.

This variation in HCV infection among different centers may be attributed to the difference in durations that these patients were on maintenance dialysis and on the preventive strategies implemented by different centers against nosocomial transmission of $\mathrm{HCV}$. The high level of $\mathrm{HCV}$ infection detected in the present work may reflect the high prevalence of HCV infection among HD patients in Egypt. This is the first report on the use of such assay in Egyptian HD and confirms earlier reports on high prevalence of $\mathrm{HCV}$ in them.

Our data showed that, the frequency of HCV RNA positivity is $18 / 20(90 \%)$ from anti-HCV positive patients. This is nearly similar to that reported by Gonzaga et al.(15) as HCV RNA was detected in serum samples from 115/154 (74.7\%) anti-HCV positive patients.

The Anti HCV antibodies detection by Murex anti HCV (version 4) ELISA revealed sensitivity, specificity and accuracy of $81.8 \%, 88.23 \%$ and $84.6 \%$ respectively. On the contrary, Marina and Teresa (22) reported sensitivity and specificity of $99 \%$ to third generation ELISA. The lower sensitivity in our study compared to this result may be attributed to the studied group who have an impaired immune response and so false negative results are common (13). On combining anti HCV positivity with elevated liver enzymes in comparison to PCR, the sensitivity decreased from $81.8 \%$ to $77.7 \%$, while the specificity was raised from $88.23 \%$ to $100 \%$ with overall accuracy from $84.6 \%$ to $91.3 \%$. This is accepted as not all HCV infected individuals have elevated liver enzymes, only 9 out of 22 RT-PCR positive patients in this study had elevated liver enzymes and this could be explained by the fact that acute hepatitis is icteric in only $20 \%$ of patients and rarely severe. The majority of patients who develop chronic HCV infection are asymptomatic, but $60-80 \%$ develop chronic hepatitis as indicated by elevated alanine aminotransferase (ALT), around 30\% maintain persistently normal ALT levels despite having detectable HCV-RNA in serum (21).

Concerning the early diagnosis of $\mathrm{HCV}$ infection in seronegative HD patients, the HCV RNA was detected in 4 $\mathrm{HCV}$ seronegative patients. These patients were on maintenance HD and mostly with impaired immune response. They may be either in the window period or low responders for the HCV antigens, thus are unable to mount detectable antibody level (20) or have occult infection (17).

As previously stated, there are several ways to assess the sensitivity of the HCV combination test. One method is to determine the number of days of earlier detection of infection with $\mathrm{HCV}$, compared to $\mathrm{HCV}$ antibody detection and $\mathrm{HCV}$ NAT. A second method is to determine the detection rate among specimens that are HCV RNA positive and anti-HCV negative (29). Our results showed that the combination assay detected 3out of $4(75 \%)$ HD patients in the window period thus the window period can be reduced by $75 \%$ when this combination assay is used in HD units.This result agrees with the previous findings, that the use of combination $\mathrm{HCV}$ core antigen and antibody assay on a fully automated chemiluminescence analyzer would detect approximately $90 \%$ of $\mathrm{HCV}$ positive blood donation obtained during the window period when this assay is utilized as an alternative to NAT (29).

The combined Ag/ Ag assay and RT-PCR results were correlated in $21 / 22$ positive and $16 / 17$ negative HCV sera. This is in agreement with the previously published data using the Monolisa HCV Ag-Ab Ultra (1) and Abbott Murex Ag/Ab (3).

Similarly Hamaied et al. (16) compared the diagnostic performance of Monolisa HCV Ag/Ab ULTRA, with Monolisa anti $\mathrm{HCV}$ plus and found that from anti HCV negative patients, 4 samples were found low positive with $\mathrm{HCV} \mathrm{Ag} / \mathrm{Ab}$. Two anti $\mathrm{HCV}$ negative, $\mathrm{HCV}$-RNA positive patients were also negative with $\mathrm{HCV} \mathrm{Ag/Ab}$ and 13 low positive samples with Biorad $\mathrm{Ab}$ were found negative with $\mathrm{Ag} / \mathrm{Ab}$. 
Laperche et al. (19) found that from the 44 samples collected during window period that were minipool nucleic acid testing positive, $31(70.5 \%)$ were also positive with the Monalisa $\mathrm{HCV}$ antigen/antibody assay and the specificity analyzed in 2503 consecutive blood donations was estimated at 99.88\%. Moreover Laperche et al. (20) in another publication found that $6 / 12$ blood donor samples positive for HCV RNA and $\mathrm{HCV}$ core $\mathrm{Ag}$. but negative for anti-HCV antibodies were positive by the HCV Ag/Ab assay and that the $24 \mathrm{HCV}$ RNA negative samples from HD patient were negative by the HCV $\mathrm{Ag} / \mathrm{Ab}$ assay and only 23 of the $59 \mathrm{HCV}$ RNA positive samples $(39 \%)$ were positive by $\mathrm{Ag} / \mathrm{Ab}$ test.

In conclusion Murex combined $\mathrm{Ag} / \mathrm{Ab}$ test helps early diagnosis of $\mathrm{HCV}$ infection by reducing the window period, preventing silent infection in high risk populations and thus reducing the risk of spreading the infection within the community. The sensitivity, specificity and accuracy of the test is higher than anti $\mathrm{HCV}$ detection test especially if combining the positivity of its results with elevated liver enzymes .Moreover, it offers many advantages as: it does not require long incubation period or considerable skills, with high reproducibility and high cost efficiency ratio. It could be a feasible alternative when NAT cannot be used.

\section{REFERENCES}

1. Alados-Arboledas, J.C.; Calbo-Torrecillas, L.; López-Prieto, M.D.; de Francisco-Ramírez, J.L.; de Miguel-Sastre, C. (2007) Clinical assessment of Monolisa HCV Ag-Ab ULTRA (Bio-Rad) in a general hospital. Enferm Infecc Microbiol Clin. 25(3):172-176.

2. Alavian, S.M. (2009). A shield against a monster: Hepatitis C in hemodialysis patients. World J Gastroenterol. 14; 15(6):641-646.

3. Alzahrani, A.J. (2008). Simultaneous detection of hepatitis C virus core antigen and antibodies in Saudi drug users using a novel assay. $\mathrm{J} \mathrm{Med}$ Virol. 80(4):603-606

4. Aoyagi, K.; Ohue, C.; Iida, K.; Kimura, T.; Tanaka, E.; Kiyosawa, K.; Yagi, S. (1999). Development of a simple and highly sensitive enzyme immunoassay for HCV core antigen. J. Clin. Microbiol., 37, 1802-1808.

5. Barrera, J.M.; Francis, B.; Ercilla, G.; Nelles, M.; Achord, D.; Darner, J.; Lee, S.R. (1995). Improved detection of anti-HCV in post-transfusion hepatitis by a third-generation ELISA. Vox Sang., 68, 15-18.

6. Bezerra, C.S.; Lima, M.C.; Vilar, J.L.; Moreira, J.L.B.; Frota, C.C. (2007). Viral hapatitis $\mathrm{C}$ in a leading Brazilian hospital: epidemiological factors and genotyping. Braz. J. Microbiol., 38 (4),656-666

7. Busch, M. (2001) Closing the windows on viral transmission by blood transfusion. In: Stramer, S.L., ed. by Bethesda, American Association of Blood Banks, pp. 33-54.

8. Busch, M.P.; Tobler, L.H.; Gerlich, W.H.; Schaefer, S.; Giachetti, C.; Smith, R. (2003). Very low level viremia in HCV infectious unit missed by NAT. Transfusion ,43, 1173-1174.

9. Centers for Disease Control and Prevention (CDC) (2001). Recommendations for preventing transmission of infections among chronic hemodialysis patients. $M M W R, 50$ (No. RR-5): 1-41.

10. Courouce, A.M.; Pillonel, J. (1996). Transfusion-transmitted viral infections. Retrovirus and Viral Hepatitis Working Groups of the French Society of Blood Transfusion. N. Engl. J. Med., 335, 1609-1610.

11. Eassa, S.; Eissa, M.; Sharaf, S.M.; Ibrahim, M.H.; Hassanein, O.M. (2007). Prevalence of hepatitis C virus infection and evaluation of a health education program in el-ghar village in zagazig, Egypt. J. Egypt. Public Health Assoc., 82, 5-6,:379-404.

12. Fabrizi, F.; de Vecchi, A.F.; Como, G.; Lunghi, G.; Martin, P. (2005). De novo $\mathrm{HCV}$ infection among dialysis patients: a prospective study by $\mathrm{HCV}$ core antigen ELISA assay. Aliment. Pharmacol. Ther. Apr 1, 21(7), 861869.

13. Fabrizi, F.; Poordad, F.F.; Martin, P. (2002). Hepatitis C infection and the patient with end-stage renal disease. Hepatology, 36, 3-10.

14. Gallarda, J.L.; Dragon, E. (2000). Blood screening by nucleic acid amplification technology: current issues, future challenge . Mol. Diagn. 5, 11-22.

15. Gonzaga, R.M.S.; Rodart, I.F.; Reis, M.G.N.; Cícero, E.R.; Silva, D.W. (2008). Distribution of Hepatitis C virus (HCV) genotypes in seropositive patients in the state of Alagoas, Brazil. Braz. J. Microbiol., 39 (4), 644647.

16. Hmaïed, F.; Ben Mamou, M.; Arrouji, Z.; Slim, A.; Ben Redjeb, S. (2007). Use of combined detection of hepatitis $C$ virus core antigen and antibodies to reduce the serological window-phase. Pathol. Biol. (Paris). Mar, 55(2), 121-126.

17. Jain, P.; Nijhawan, S. (2008). Occult hepatitis C virus infection is more common than hepatitis B infection in maintenance hemodialysis patients. World J. Gastroenterol. Apr 14(14), 2288-2289.

18. Laperche, S.; Bouchardeau, F.; Maniez, M.; Béolet, M.; Elghouzzi, M.H.; Lefrère, J.J. (2004). Nucleic acid testing in blood donations reactive to hepatitis $\mathrm{C}$ virus antibody, but with an extremely low viral load. Vox Sang. 86 (3), 198.

19. Laperche, S.; Elghouzzi, M.H.; Morel, P.; Asso-Bonnet, M.; Le Marrec, N.; Girault, A.; Servant-Delmas, A.; Bouchardeau, F.; Deschaseaux, M.; Piquet, Y. (2005). Is an assay for simultaneous detection of hepatitis C virus core antigen and antibody a valuable alternative to nucleic acid testing? Transfusion, Dec., 45(12), 1965-1972.

20. Laperche, S.; Le Marrec, N.; Girault, A.; Bouchardeau, F.; ServantDelmas, A.; Maniez-Montreuil, M.; Gallian, P.; Levayer, T.; Morel, P.; Simon, N. (2005). Simultaneous detection of hepatitis C virus (HCV) core 
antigen and anti-HCV antibodies improves the early detection of $\mathrm{HCV}$ infection. J. Clin. Microbiol. Aug., 43(8), 3877-3883.

21. Leone, N.; Rizzetto, M. (2005); Natural history of hepatitis C virus infection: from chronic hepatitis to cirrhosis, to hepatocellular carcinoma. Minerva Gastroenterol. Dietol. 51(1), 31-46.

22. Marina, B.; Teresa, L. (2006). Hepatitis C Transmission In Feldman: Sleisenger and Fordtran's Gastrointestinal and Liver Disease, 8th ed., Elsevier, pp. 1686.

23. Medhi, S.; Potukuchi, S.K.; Polipalli, S.K.; Swargiary, S.S.; Deka, P.; Chaudhary, A.; Begum, N.; Hussain, Z.; Ahlawat, R.S.; Kar, P. (2008). Diagnostic utility of hepatitis $\mathrm{C}$ virus core antigen in hemodialysis patients. Clin. Biochem. 41(7-8), 447-452.

24. Nübling, C.M.; Unger, G.; Chudy, M.; Raia, S.; Löwer, J. (2002). Sensitivity of HCV core antigen and HCV RNA in early infection phase. Transfusion 42, 1037-1045.

25. Operskalski, E.A.; Mosley, J.W.; Tobler, L.H.; Fiebig, E.W.; Nowicki, M.J.; Mimms, L.T.; Gallarda, J.; Phelps, B.H.; Busch, M.P. (2003). HCV viral load in anti-HCV-reactive donors and infectivity for their recipients. Transfusion 43, 1433-1441.

26. Pawlotsky, J.M. (1999). Diagnostic tests for hepatitis C. J. Hepatol. 31(Suppl. 1), 71-79.

27. Ré, V.; Gallego, S.; Treviño, E.; Barbás, G.; Domínguez, C.; Elbarcha, O.; Bepre, H.; Contigiani, M. (2005). Evaluation of five screening tests licensed in Argentina for detection of hepatitis $\mathrm{C}$ virus antibodies. Mem. Inst. Oswaldo. Cruz. 100, 303-307.

28. Schneeberger, P.M.; Toonen, N.; Keur, I.; van Hamersvelt, H.W. (1998).
Infection control of hepatitis C in Dutch dialysis centres. Nephrol. Dial. Transplant. Dec, 13(12), 3037-3040

29. Shah, D.O.; Chang, C.D.; Jiang, L.X.; Cheng, K.Y.; Muerhoff, A.S.; Gutierrez, R.A.; Leary, T.P.; Desai, S.M.; Batac-Herman, I.V.; Salbilla, V.A.; Haller, A.S.; Stewart, J.L.; Dawson, G.J. (2003). Combination HCV core antigen and antibody assay on a fully automated chemiluminescence analyzer. Transfusion. 43(8), 1067-1074.

30. Thongsawat, S.; Maneekarn, N.; Kuniholm, M.H.; Pantip, C.; Thungsuputi, A.; Lumlertkul, D.; Bannachak, D.; Nelson, K.E. (2008). Occult hepatitis $\mathrm{C}$ virus infection during an outbreak in a hem Thailand. J. Med. Virol. 80(5), 808-815.

31. Tokars, J.I.; Finelli, L.; Alter, M.J.; Arduino, M.J. (2004). National surveillance of dialysis-associated diseases in the United States. Semin. Dial. 17, 310-319.

32. Urdea, M.S. (1993). Synthesis and characterization of branched DNA (bDNA) for the direct and quantitative detection of CMV, HBV, HCV, and HIV. Clin. Chem. 39, 725-726.

33. Xie, L.; Wu, X.D.; Huang, D.Z.; Chen, H.L.; He, L.X.; Wang, J.; Han, D.K. (2007). Clinical application and analysis of hepatitis C virus NS3 antigen detection by ELISA in human serum. Chin. Med. J. (Engl). 120(4), 294-299.

34. Yakaryilmaz, F.; Gurbuz, O.A.; Guliter, S.; Mert, A.; Songur, Y.; Karakan, T.; Keles, H. (2006). Prevalence of occult hepatitis B and hepatitis $\mathrm{C}$ virus infections in Turkish hemodialysis patients. Ren. Fail. 28(8), 729-735. 